\title{
Mechanical and Thermophysical Properties of Hot-Pressed SYNROC B
}

\author{
C. L. Hoenig \\ H. W. Newkirk \\ R. A. Otto \\ R. L. Brady \\ A. E. Brown \\ A. R. Ulrich \\ R. C. Lum
}

Manuscript date: May 6, 1981

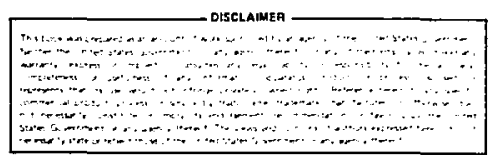

\section{LAWRENCE LIVERMORE LABORATORY}

University of California $\bullet$ Livermorc, California $\bullet 94550$ 


\section{CONTENTS}

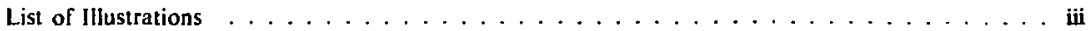

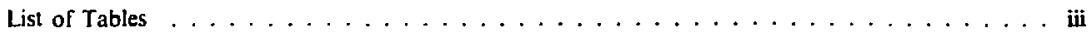

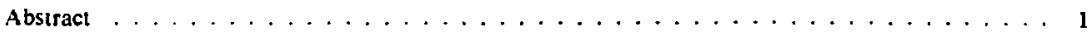

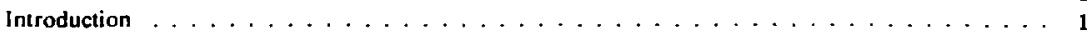

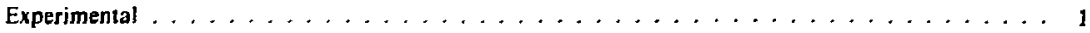

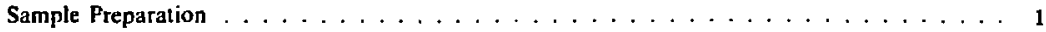

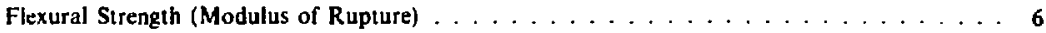

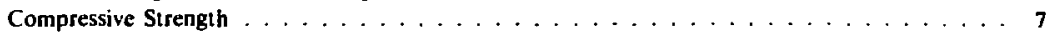

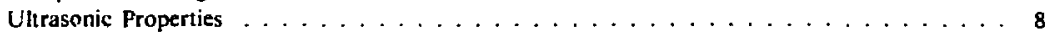

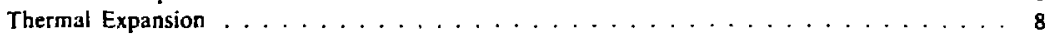

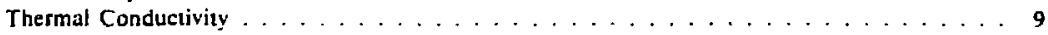

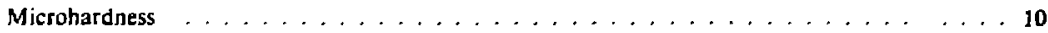

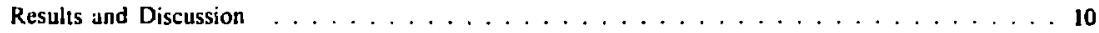

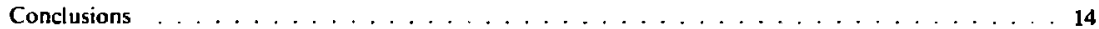

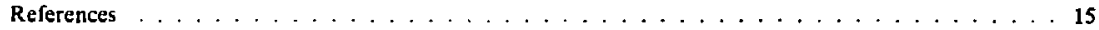




\section{LIST OF ILLUSTRATIONS}

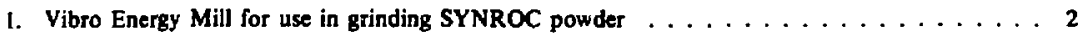

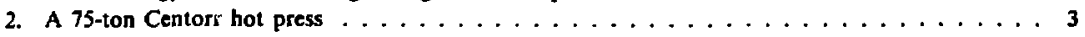

3. Graphite die for hot pressing a 15.2-cm-diam SYNROC sample . . . . . . . . . . 3

4. SYNROC sample after hot pressing . . . . . . . . . . . . . . . . . . . . 4

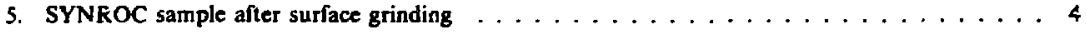

6. SYNROC sample after being cut and ground into special shapes . . . . . . . . . . . 5

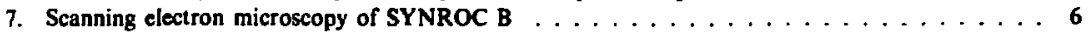

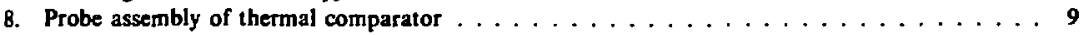

9. Thermal expansion of SYNROC B . . . . . . . . . . . . . . . . 12

\section{LIST OF TABLES}

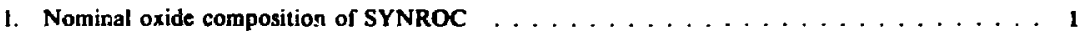

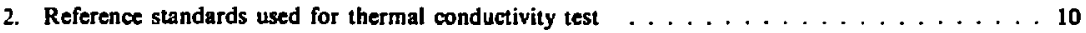

3. Ultrasonic test report on SYNROC B MOSHP4A . . . . . . . . . . . . . . . . 10

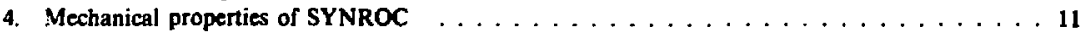

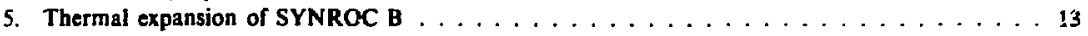

6. Thermal-expansion coefficients of various titanates and SYNROC B . . . . . . . . 13

7. Thermal conductivity of $\mathrm{TiO}_{2}$, titanates, and SYNROC B and C . . . . . . . . . . 14 


\title{
Mechanical and Thermophysical Properties of Hot-Pressed SYNROC B
}

\begin{abstract}
The optimal SYNROC compositions for use with commercial waste are reviewed. Large amounts of powder (about $2.5 \mathrm{~kg}$ ) were prepared by conventional ceramic operations to test the SYNROC concept on a processing scale. Samples, $15.2 \mathrm{~cm}$ in diameter, were hot pressed in graphite, and representative samples $w$ re cut for microstructural evaluations. Measured mechanical and thermophysical properties did not vary significantly as a function of sample location and were typical of titanate ceramic materials.
\end{abstract}

\section{INTRODUCTION}

The SYNROC concept for incorporating radiation-waste (rad-waste) elements in a synthetic. titanate mineral assembiage was introduced by Ringwood in 1978. ${ }^{1.2}$ These concepts are being applied to $U$. S. defense wastes by the Mineral Waste Form Program at LLNL. SYNROC B, a basic waste form without rad-waste elements, consists primarily of three titanate-minera! phases-zirconolite $\left(\mathrm{CaZrTi}_{2} \mathrm{O}_{7}\right)$. perovskite $\left(\mathrm{CaTiO}_{3}\right)$, and a hollandite analozue $\left(\mathrm{BaAl}_{2} \mathrm{Ti}_{6} \mathrm{O}_{16}\right)$. The results of other studies on the application of SYNROC C to commercial wastes ${ }^{3-6}$ and of SYNROC D to U. S. defense waste $e^{7-11}$ are reparted elsewhere.

The purpose of this study is to evaluate some of the mechanical and thermophysical properties of basic SYNROC B that are important to riskanalysis studies concerned with the preparation, transportation, arit' storage of nuclear waste. These results will also be compared kith later formulations of SYNROC C and D.

\section{EXPERIMENTAL}

\section{SAMPLE PREPARATION}

The oxide composition (M05) used in this study is shown in Table 1 . Also shown in Table 1 is a recent and improved formulation recommended by Ringwood ${ }^{2}$ in which the nominal molecular ratic for hollandite ( $\mathrm{BaO}: \mathrm{Al}_{2} \mathrm{O}_{3}: \mathrm{TiO}_{2}$ ) was changed from 1:1:6 to 1:1:7.

In a lypical formulation for commercial waste. Ringwood proposes 88 wi\% SYNROC. 2 wt $\%$ Ti metal, and $10 \mathrm{wi}^{\circ} \mathrm{s}$ waste.

The starting materials were pigment-grade $\mathrm{TiO}_{2}$ rutile (N.L. Chemical Co., South Amboy. N. J. 08879); zirconium dioxide $\left(\mathrm{ZrO}_{2}\right)$ reactor grade, Teledyne Wah Chang. Albany, Oregon 97321): and reagent grade hydroxides of barium. calcium, and aluminum. We now prefer to use an
TABLE 1. Nominal oxide composition of SYNROC.

\begin{tabular}{|c|c|c|}
\hline Oxile & $\begin{array}{l}1105^{n} \\
\left(m r^{2}\right)\end{array}$ & $\begin{array}{l}\text { Ringenood's } \\
\text { preferted } \\
\text { (nt'r) }\end{array}$ \\
\hline $\mathrm{FiO}_{2}$ & 57.2 & 62.2 \\
\hline CaO & 16.2 & 10.0 \\
\hline $\mathrm{ZrO}_{2}$ & 12.4 & $6 . y$ \\
\hline 800 & B.. & I5.0 \\
\hline \multirow{2}{*}{$+\mathrm{I}_{2} \mathrm{O}_{3}$} & 5.5 & 5.9 \\
\hline & IGLO & $\overline{100.0}$ \\
\hline
\end{tabular}

"Composition cakelated on the besis of tI ur., mollantite (t:1:b). 35 wt't zircomolite, and 25 wt'e prosskit".

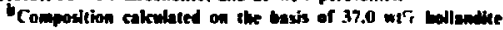

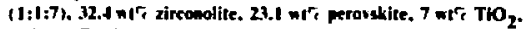
and 1 wte $\mathrm{Al}_{2} \mathrm{O}_{3}$. 
anatase grade of $\mathrm{TiO}_{2}$, which we find to be more reactive in the synthesis of SYNROC mineral phases.

A batch with an oxide equivalent of about 2.5 $\mathrm{kg}$ was cone blended with a high intensity bar for 16 hours. The powders were then calcined in air at $1000^{\circ} \mathrm{C}$ for 16 hours to a constant weight and ground as an aqueous slurcy with $\mathrm{Al}_{2} \mathrm{O}_{3}$ balls in a Sweco Vibro Energy Mill, model M18-5 (see Fig. 1). The powder mixture was air dried at $200^{\circ} \mathrm{C}$ and cone blended a second time for 18 hours. An x-ray patiern of this powier shoucd only perovskite formation plus unreacted $\mathrm{TiO}_{2}, \mathrm{ZrO}_{2}$, and some unidentified peaks.

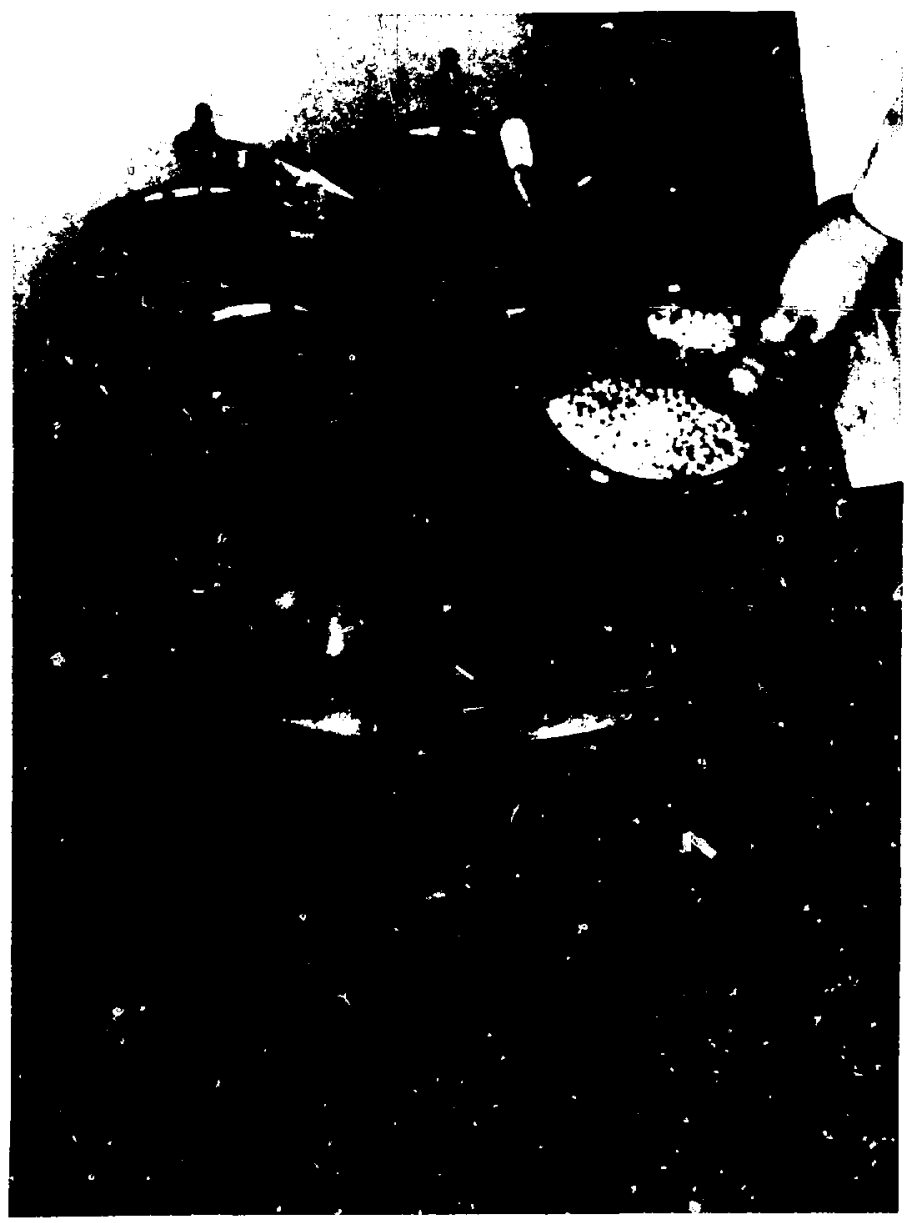

FIG. I. Vibro Energy Mill for use in grinding SYNROC powder. 
We conducted preliminary small-scale $1.6-\mathrm{cm}-$ diam hot pressings to establish the temperature, pressure, and time parameters necessary to achieve $99 \%$ of theoretical density which was taken as 4.23 $\mathrm{g} / \mathrm{cm}^{3}$ and was based on the pycnometric density of SYNROC B crushed and ground to -325 mesh powder.

For the large hot pressing (15.2-cm-diam), we prepressed $800 \mathrm{~g}$ of powder at $2000 \mathrm{psi}$ in an ATJ graphite die to a density of $1.91 \mathrm{~g} / \mathrm{cm}^{3}$ (45\% of theoretical). The graphite die was positioned by hand onto the lower platen of a double-acting hot press (Fig. 2 and 3), which could be operated in either a vacuum or an inert-atmosphere. A 3-phase, tungsten-mesh heating element surrounded the graphite die and punches. Temperature was measured by thermocouple and optical pyrometer.

The sample (M05HP4A) was slowly heated under vacuum ( $10^{-4}$ Torr) to $1200^{\circ} \mathrm{C}$ in 4 hours under a uniaxial pressure on the sample of $800 \mathrm{ps}$. At $1200^{\circ} \mathrm{C}$, the maximum pressure of $2000 \mathrm{psi}$ was applied and maintained for a l-hour period under a

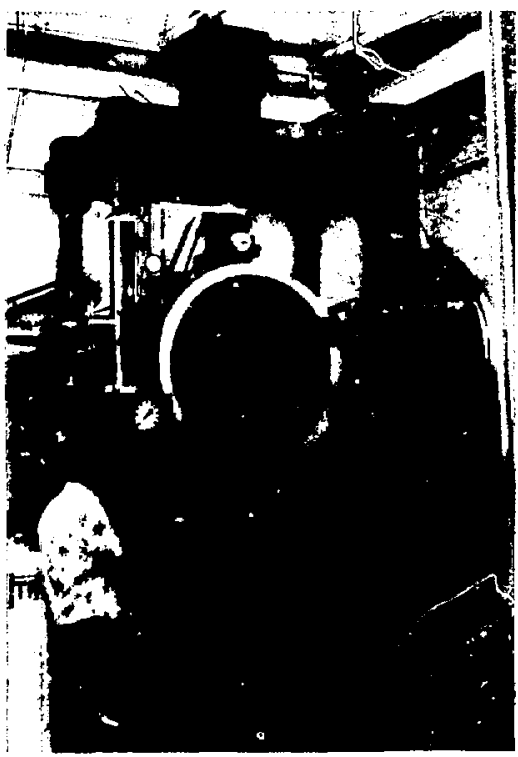

FIG. 2. A 75-ton Centorr hot press.

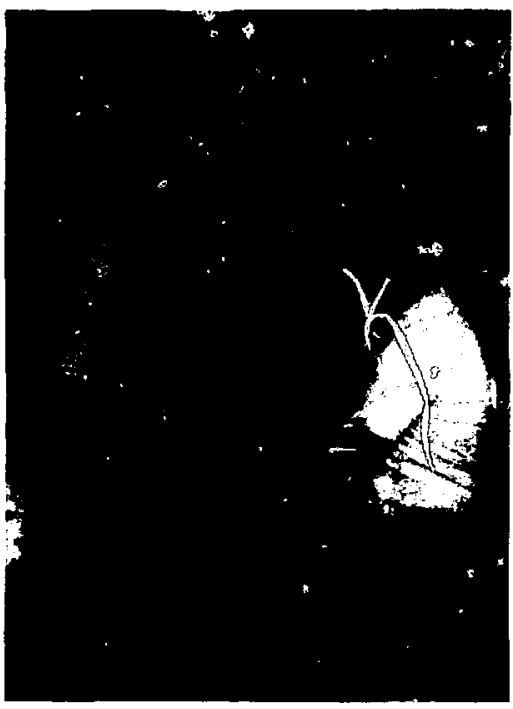

FIG. 3. Graphite die for hot pressing a $15.2-\mathrm{cm}-$ diam SYNROC sample.

vacuum of $7.0 \times 10^{-5}$ Torr. At the end of the hold period, the pressure was released and furnace power was terminated. The sample cooled slowly to room temperature over a period of 16 hours. The sample was easily removed from the graphite die, and no visual reactions between the sample and graphite die were observed. The hot-pressed sample is shown in Fig. 4, and the sample after surface grinding in Fig. 5.

The sample was then cut and ground into special shapes for studies of mechanical and thermophysical properties. The finished specimens are shown in Fig. 6. Four samples for ultrasonic testing (a) were taken from the cenier and edge locations, two each, of the large disc to assess property variations across the diameter. Two larger samples (b) for tests of nexural strengih (modulus of rupture) were taken from an intermediate edge-to-center location. Two samples for thermal expansion (c) were taken from edge and center locations. Samples for compression testing (d) and bearing blocks to minimize end effects were also taken from edge and center locations. 


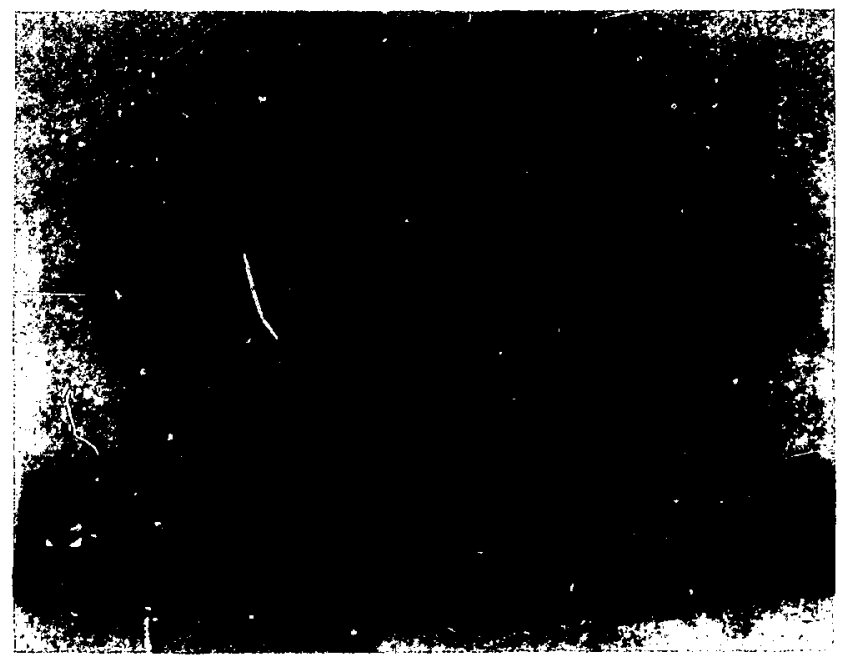

FIG. 4. SYNROC sample after hot pressing.

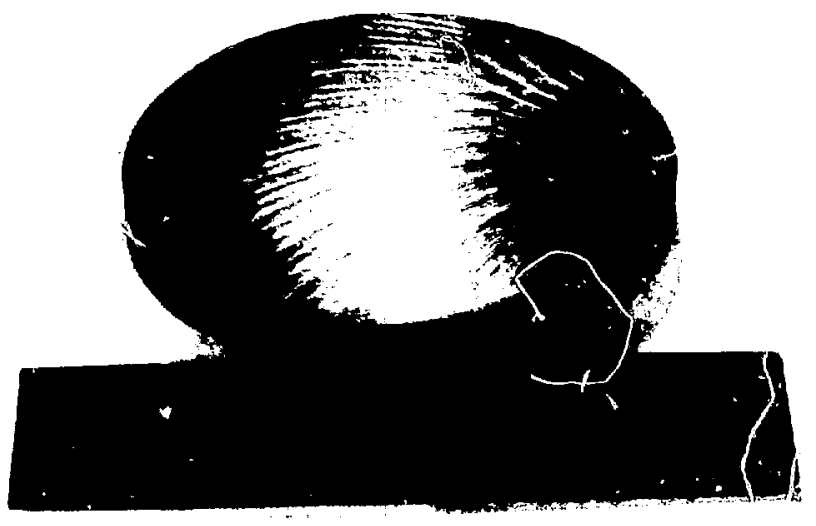

FIC. 5. SYNROC semple after surface grinding. 


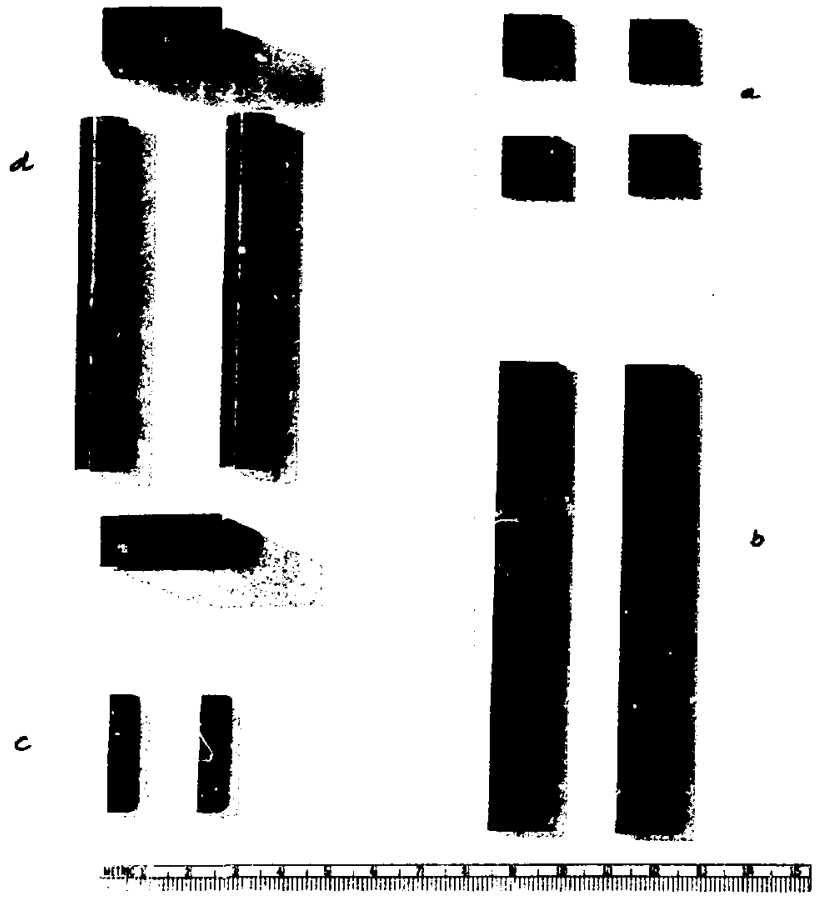

FIG. 6. SYNROC sample after being cut and ground into special shapes for use in studies of mechanical and thermophysical properties. Specimens were cut from center and edge locations of sample disc to assess property : ariations across the diameter. (a) Samples for ultrasonic testing. (b) Samples for flexural strength (modulus of rupture). (c) Samples for thermal expansion. (d) Samples for compression testing and for bearing blocks to minimize end effects. 
The microstructure and phase development of SYNROC B were studied by scanning electron microscopy (SEM) and $x$-ray diffraction. In Fig. 7, the SEM micrograph shows grain sizes on the order of $1 \mu \mathrm{m}$. The mottled phase is a mixture of perovskite and zirconalite, and the dark phase is hollandite. An x-ray diffraction pattern showed all three SYNROC phases to be well developed, with only trace amounts of unknown phases.

The broken samples from flexural strength testing were sent to Dr. S. M. Wiederhorn, Fracture and Deformation Division, National Bureau of Standards, for fracture property studies including critical stress intensity to ditermine fracture and stress corrosion resistance.

\section{FLEXURAL STRENGTH (MODULUS OF RUPTURE)}

Tests for tensile strength of brittle ceramics are difficult to conduct. The low ductility of these materials makes them sensitive to the high localized stresses present at the erip contacts near the ends of samples. Therefort. a very high probability exists that premature frature will be initiated in the grip region of the specimen.

Close approximations of the monotonic tensile strength can be obtained by two alternate tests, the flexural (modulus of rupture) test and the diametral compression test. ${ }^{12-14}$ The iatter test uses a compressive loading applied along the diameter of a cylinder and results in tensile stresses across the specimen.

For this investigation, we have chosen the flexural test in which an increasing force is applied, either by one centered or by two eveniy spaced contacts. For valid testing of brittle material, such contacts with the beam must be with transfer members having a rounded impresser and pivotal action. The radius of the support assures a nonlocalized distribution of bearing stress. The pivotal action of these contacts is desired so that any possible bowing existing in the specimens may be matched. The two usual parameters recorded in this test are, first, bending force and, second, deflection of the center lower surface of the beam. These measurements are taken on an X-Y recorder as a force-vs-deflection plot. A pre-test alignment procedure is performed to position the specimen and the deflection transducer accurately. In this procedure, loading cycles at low levels (safely below yielding) are first imposed on the specimen. Positional accuracy is then hoted on the plotter output and corrections are made by relinement of the specimen position.

The dimensions of fixural specimens in this study were selected within a given relationship of thickness, width, and length and were $0.190,0.50$,

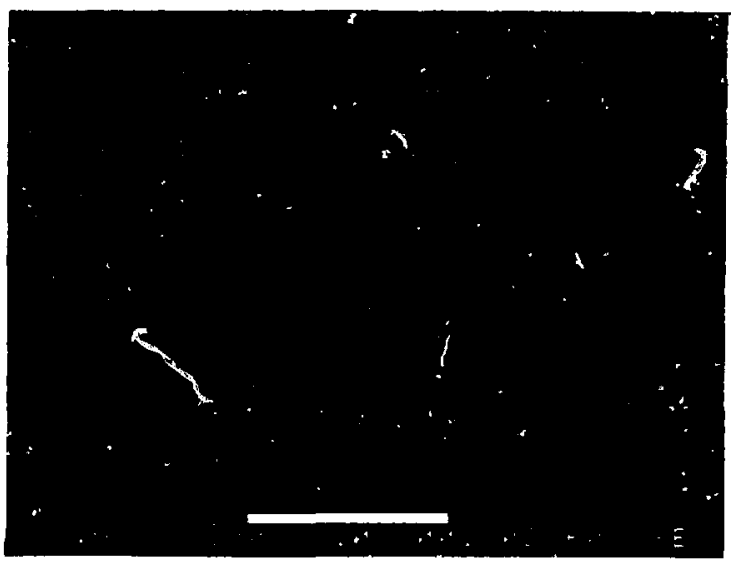

FIC. 7. Scanning electron microscopy of SYNROC B. 
and 4 in., respectively. We decided to perform a four-point rather than a three-point test. The former produces a "field" of maximum stress on the lower surface of the specimen. The selected specimens were supported during the test on 3-in. centers to oppose a bending force applies by a pair of contacts having 0.125 -in. radii and a l-in. separation. These dimensions agree with relationships suggested by ASTM specifications. ${ }^{15}$ Two material properties are determined from these flexural tests, specifically, modulus of rupture ( $M / R)$ and bending modulus ( $\left.E_{\beta}\right)$.

Modulus of rupture (flexural strength) is essentially a measure of the maximum stress (during bending) at the lower beam surface at the instant of frac:sre. The formula for determining maximum stress for the four-point flexure test is as follows:

$$
S_{\text {mix }}(M / R)=\frac{P L}{b d^{2}}
$$

where $S_{\max }(M / R)$ is maximum stress (psi), $P$ is maximum force (lb), $L$ is support span (in.), $b$ is beam width (in.), and $d$ is beam thickness (in.).

Bending modulus (modulus of elasticity in bending) is a measure of the elastic stiffness of the material in a simple beam configuration. A plot of bending force vs bending deflection for a specimen of consistent density and regularly distributed surface flaws is expected to exhibit a linear elastic response. The slope of this line is the bending modulus of elasticity. The formula for a four-point nexure test is as follows:

$$
E_{B}=\frac{0.21 L^{3} \mathrm{~m}}{b d^{3}}
$$

where $E_{B}$ is modulus of elasticity in bending (psi), 0.21 is constant for rectangular beam, $L$ is support span length (in.), $m$ is slope of tangent of initial straight line of the plot (lb/in.), $b$ is specimen wioth (in.), and $d$ is specimen thic'?ness (in.).

\section{COMPRESSIVE STRENGTH}

The determination of valid compressive mechanical properties of a material requires the careful selection of appropriate specimens anc procedures. ${ }^{16}$ One of the first considerations is the specific dimensions of the specimen. To determine properties (i.e., elastic modulus and monotonic compressive strength) with precision, a rightcircular-cylindrical specimen is a virtual necessity. A minimum cylinder-length-to-diameter ratio of 6 to 1 must be maintained to assure a condition of pure uniaxial (monotonic) stress. Under this criterion, specimen length will be sufficient to provide uniform strain in the center region of the spccimen during the entire test. This central region is the site for the fixing of electrical sirain gages, clip gages, or other types of deflection transducers. This region should be restricted to only one-tinitd of the specimen length, to again assure that this t.cluded volume of material is unaffected by the frictiona! constraint of the specimen ends.

Only a single specimen, $0.5 \mathrm{in}$. in diameter by 3 in. in length, was available at this stage of our test program. Bearing blocks, 1.25 by 1.25 by 0.5 in., were cut of the same material and were used as loading members at the ends to reduce the likelihood of premature spallation. The use of bearing blocks serves to modify and distribute stress concentrations caused by the mismatch between SYNROC with its high degree of stiffness and steel platens that $r$ sve a low degree of stiffness.

Pretest alignment of the specimen to eliminate or minimize bending loads is a necessity for accurate compression determinations on a brittle material. For this test, an LLNL-designed alignment fixture is employed. This fixture is a manually operated assembly that is topped by a circular platen upon which the specimen is centered. The unit is capable of producing both a tipping action (off the horizontal) and a lateral displacement of the platen. Adjustment for correctional specimen alignment is guided by the mounting of three clip gages (Instron extensometers) at $120^{\circ}$ positions around the center third of the specimen. The deflection output signal of each of these transducers, as well as that for correspending force, is directed to a plotter. By observing the relation of these traces, we can modify specimen bending (an indication of misalignment).

Two material properties of the specimen are evaluated. In addition to the ultimate compression fracture strength, a stiffness measurement that is expressed by elastic modulus (Young's modulus) is determined. 
The compressive fracture strength is expressed as follows:

$$
\mathrm{S}_{\mathrm{c}}=\frac{\mathbf{P}_{\mathrm{B}}}{\mathrm{A}_{0}}
$$

where $S_{c}$ is compressive fracture strength (psi), $P_{B}$ is breaking load (lb), and $A_{0}$ is specimen crosssec'ional area (in. ${ }^{2}$ ).

Through interpretation of the load-vsdeflection plot, we obtain the value for Young's modulus by determining the slope of the line to the limit of its linear region. The modulus is calculated, from the load increments and the corresponding extension increments at two points on the line, by applying the following equation:

$$
E_{c}=L_{0} \Delta_{p} / A_{0} \Delta_{e}
$$

where $\mathrm{E}_{\mathrm{c}}$ is Young's modulus-compression (psi), $\mathrm{L}_{0}$ is original gage length (in.), $\Delta p$ is load increment (lb), $A_{0}$ is original cross-sectional area (in. ${ }^{2}$ ), and $\Delta_{e}$ is extension increment (in.).

\section{ULTRASONIC PROPERTIES}

The method used to determine the ultrasonic properties of materials is well documented in the literature. ${ }^{17-21}$ The technique employed (in part) in these SYNROC studies is the "Pulse-Overlap Method" developed by Papadakis. ${ }^{22-24}$ One pulse overlap system was purchased from Matec Corporation and another from Panametrics, Inc. No absolute corrections were attempted for phase shifts caused by the junction of the near-field and far-field echoes of ultrasound. Neither were corrections made for the seal interfaces. The ultrasound velocity corrections as a percentage of the measured velocities are very small unless the specimen is thin and also has very high moduli. The use of highly damped, high-frequency, ultrasonic transducers coupled with a digital exciting pulse permits an accuracy of one part per thousand with most specimens. The additional computational and experimental time required to correct the velocities to an accuracy of one part per hundred thousand is usually not justified. First, it may not be cost effective; and secend, the thickness and parallelism of the specimens may not be uniform enough or accurate enough to meet the stringent requirements for making such velocity corrections.

\section{THERMAL EXPANSION}

Thermal exparsion measurements on SYNROC were performed according to ASTM E-228-71 (Standard Test Method for Linear Expansion of Rigid Solids with a Vitreous Silica Dilatometer). Minor modifications were made to the dilatometer and test procedure.

The thermal linear-expansion apparatus consists of a Brinkmars furnace with a two-inch constant heating zone, a West cam-driven temperatureramping controller, an LLNL designed, horizontal. positioned, quartz dilatometer with a linear voltagedisplacement transducer (LVDT). Type S (Pt-10\% $R h)$ thermocouples are used for temperature measurement and control.

A tiermocouple is attached to the test specimen by tightly wrapping a platinum wire around both the bead of the thermocouple and the test specimen. The latter is then inserted into the quartz-tube dilatometer, ensuring the correct alignment of the test specimen, transmission rod, and LVDT. This entire assembly is inserted into a quartz protection tube such that the test specimen is located in the furnace zone of constant temperature. Inert argon gas flows around the test specimen for the duration of the test. The heating rate to $950^{\circ} \mathrm{C}$ is approximately $3^{\circ} \mathrm{C} /$ minute. The length change versus temperature is traced with an $X-Y$ recorder during the test.

The SYNROC test specimens were rods, 2.54 by 0.48 by $0.48 \mathrm{~cm}$. Two test runs were made for each of the two specimens submitted. Ten points were selected from the trace of the change in length vs temperature. For the reported data, we made corrections for changes in length of the quartz dilatometer by us.ng the following formula:

$$
\Delta \mathrm{L} / \mathrm{L}_{0}=(\Delta \mathrm{L})_{\mathrm{a}} / \mathrm{L}_{0}+(\Delta \mathrm{L})_{\mathrm{s}} / \mathrm{L}_{0}
$$

where $L_{0}$ is lenf, $f$ test specimen at ambient temperature, $(\Delta L)_{a}$ indicates ap rent changes in specimen length in going from test temperature $T_{1}$ to temperature $T_{2}$, and $(\Delta L)_{5} / L_{s}$ is change in length per unit length of quartz in going from $T_{1}$ to $T_{2}$. 


\section{THERMAL CONDUCTIVITY}

The thermal conductivity at room tempersure was measured approximately and cc.npared to reference standards by usith a thermal comparalc $\tau$ (TPRC Thermal Comparátor, Model 100, McClu?e Park Corporation, 2595 Yeager Road, Test Lafayette, Indiana 47906).

The thermal is nparator registers the rate of cooling experienced by the tip of a heated probe on contact with the surface of a material. The probe assembly, shown schematically in Fig. 8, consists of a sensing tip, a heater, and a thermal reservoir, held at temperature $T_{\text {, }}$ above the room temperatare $T_{2}$. Upon contact of the surface of the material (thermal conductivity $\lambda_{2}$ ) with the probe tip. of thermal conductivity $\lambda_{1}$, the temperature of the tip of the probe quickly drops to an intermediate temperature $T_{c}$, according to the relation

$$
\mathrm{T}_{\mathrm{c}}=\frac{\mathrm{T}_{1} \lambda_{1}+\mathrm{T}_{2} \lambda_{2}}{\lambda_{1}+\lambda_{2}} \text {. }
$$

The thermal comparator employs a thermocouple whose thermoelectric junction is verv near the end of the sensing tip and is differentially connected with another junction located within the thermal reservoir. This differential reading $T_{1}-T_{c}$ is given by

$$
T_{1}-T_{c}=\lambda_{2}\left(T_{1}-T_{2}\right) /\left(\lambda_{1}+\lambda_{2}\right)
$$

The exast location of the sersing thermocouple tip is vita' to the proper operation of the comparator. Maximum sensitivity and freedom from influence oiload (pressure) is obtained when the thermocouple junction is the contact interface. This ( Indition obtains when the probe material and the test sample constitute the two elements of the thermocouple. Because this condition does not generally obtain in practice, experience requircs that ihe tinermocouple be located is close to the tip as possible and that the load or the prube be carefully controlled to a constant value. The reference standards used in this test are given in Table 2. Our moasured values were accurate to within $\pm 10 \%$.

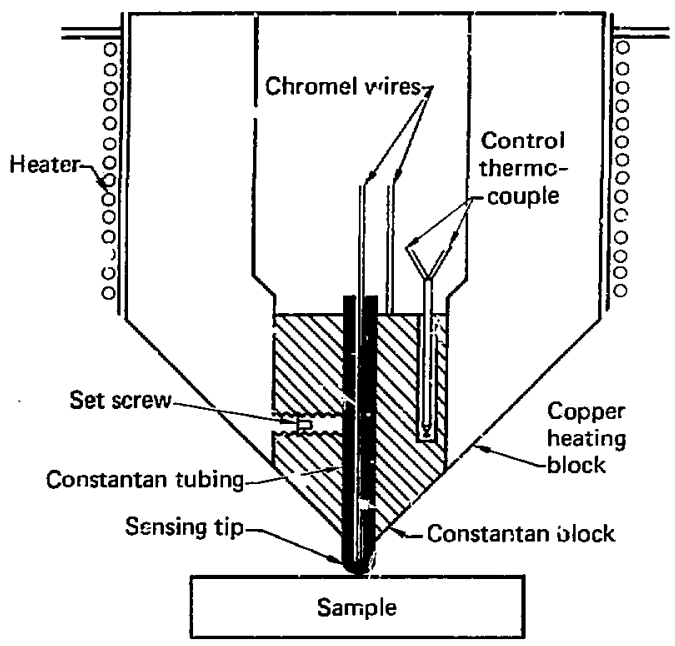

FIG. 8. Probe assembly of thermal comparator. 


\section{MICROHARDNESS}

Hardness measurements were made with a Knoop indenter using a Leitz Durimet SmallHardness Tester (Ernst Leitz (Canada) Lid., Midland, Ontario). Measurements were taken with 50-, 100-, and 500-gram loads. Average values were determined from three to six measurements, and errors were reporked as the standard deviation $(\sigma)$.
TABLE 2. Refereace standerds used for thermal conductivity test.

\begin{tabular}{|c|c|}
\hline Material & 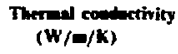 \\
\hline Ebowite & 0.18 \\
\hline Code 7740 glass & 1.15 \\
\hline Fused partz & 1.4 \\
\hline No. 110 AT :Ti, SA, 2.5Sm) alloy & 7.8 \\
\hline Na. 316 stainless steel & 14 \\
\hline Armco iron & 75 \\
\hline
\end{tabular}

\section{RESULTS AND NISCUSSION}

The ultrasonic test results of four samples from edge and center locations are shown in Table 3. Averaged values arc shown in Table 4 with the combined results of the other tests.

The ult rasonjc velocity measurements on SYNROC were performed with highly domped transducers having nominal frequencies of 5 and $10 \mathrm{MHz}$ for determining the distortional ind compressional wive speeds, respectivcly. The transducers were fitted with i low-acoustic-impedance delay line to avoid phase reversals hetween echoes from the SYNROC samples. The first and second echces returning frum the SYNROC overlapped on the os- cilloscope screen. and the frequency required to produce this overlap was recorded. The frequency is easily measured to six or seven places. The visual ability to produce the overtap depends on the surface finish, thickness, parallelism, and homogeneity of the specimen. The surface finish of the SYNROC samples was such that it was amenable to visual overlap precisions of one in twenty thousand frequeniy. Rotation of the distortional-wave-particic direction did not change the frequency that produced the overlip. Therefore, it is concluded that the samples were each isotropic and essentially strain free in rotation through the faces.

TABLE 3. Uttrasonic test report ${ }^{2}$ on SYNROC B MOSHP4A.

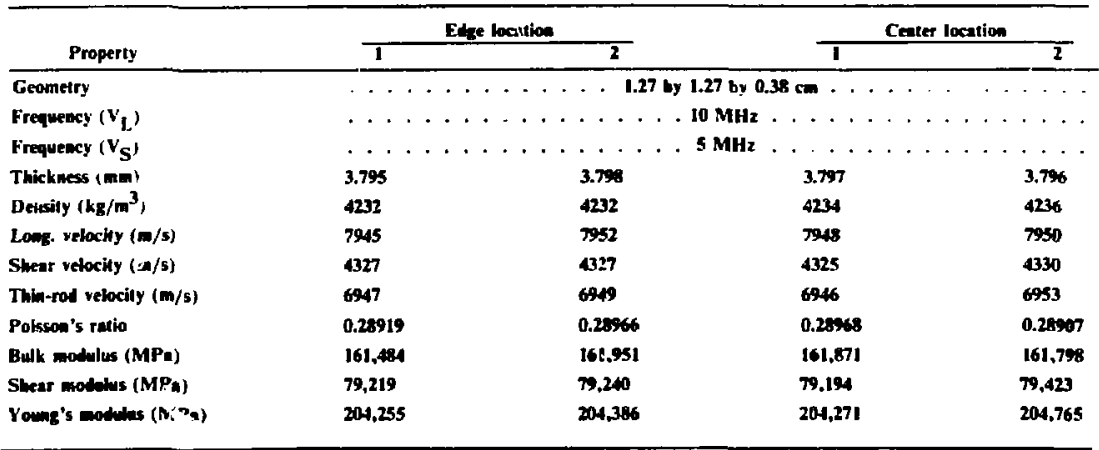

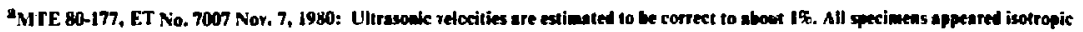
to shear wave proparalion. 
TABLE 4. Mechanical properties of SYNROC.

\begin{tabular}{|c|c|c|c|}
\hline \multirow[b]{2}{*}{ Property } & \multicolumn{2}{|c|}{ SY;iROC $\mathbf{B}^{\mathbf{b}}$} & \multirow[b]{2}{*}{ SYNROC $C^{c}$} \\
\hline & Fdze loristion & Center location & \\
\hline Tensile strength ( $1 \mathrm{P}_{\mathrm{a}}$ ) & - & - & 75.6 \\
\hline Flexural strength (MPa) & $295 \pm 31$ & - & - \\
\hline ('ompressive strength [MPa) & - & $\begin{array}{l}574 \\
\text { (single sample) }\end{array}$ & 810 \\
\hline \multicolumn{4}{|l|}{ Flastic constants: } \\
\hline \multicolumn{4}{|l|}{ Young's modulus (GPa): } \\
\hline I Jurasonic & $2(14.3$ & 204.5 & 2013.3 \\
\hline Modulus of rupture & $142 \pm 6$ & - & - \\
\hline Campression & & 248 & - \\
\hline \multicolumn{4}{|l|}{ Buik modulus (GiPar: } \\
\hline L'Itrasenic & 161.8 & 161.8 & 161.2 \\
\hline \multicolumn{4}{|l|}{ Shear modulus $($ ( P a $)$ : } \\
\hline IHrasonic & 79.2 & 74.3 & 78.8 \\
\hline \multicolumn{4}{|l|}{ Vicrohardness $\left(\mathrm{kg}^{\prime} / \mathrm{mm}^{2} \mathrm{~s}\right.$} \\
\hline$|H K\rangle_{\text {st }}$ & $1079 \pm 35$ & $110 y=13$ & - \\
\hline$H K N_{\text {t(n) }}$ & $102 n+9$ & $1017 \pm 10$ & - \\
\hline $\mathrm{HKN}_{\mathbf{s}(\mathrm{K})}$ & $884 \pm 37$ & $875 \pm 21$ & - \\
\hline
\end{tabular}

\footnotetext{
"Hirrors are calculated as siandard doviations iol.

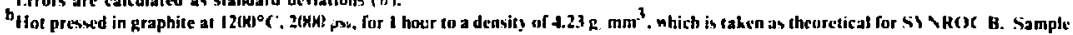
diameter is $15.2 \mathrm{~cm}$.

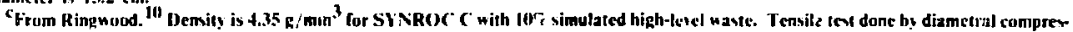
siun. Compressise specimens Here $11.5 \mathrm{~cm}$ lethe by $0.5 \mathrm{~cm}$ in diameter, giring an $I$. 13 ratio of 1.18 .
}

The results of flexural and compressive tests and microhardness measurements are shown in Table 4. Also shown are the data of Ringwood ${ }^{10}$ for SYNROC C containing 10, simulated high-level waste.

The densities of SYNROC C combinations with high-level waste and with small percentages of metal are approximately $4.35 \mathrm{~g} / \mathrm{cm}^{3}$. This is slightly higher than the $4.23 \mathrm{~g} / \mathrm{cm}^{3}$ taken as theoretical for SYNROC B alone, without these additions. The 4.23 density value is based on mercury porosimetry nealsurement of hot-pressed samples.

The results in Tabic $\$$ indicate litle variation in properties from center 10 edgc in the large 15.2-cn!dianneter hot-pressed sample. The strength values are unfortunately based on only a few measurements and more data is needed. The flexural sirength of $295 \pm 31 \mathrm{MP}$ a compares very well with a commercial grade $85 \% \mathrm{Al}_{2} \mathrm{O}_{3}$ eeramic. The clastic properies of our sample also compare well with commercial alumina. The difference between the elastic properties of SYNROC 8 and $C$ is minor, in- dicating that the addition of $10 " \%$ high-level waste does not appreciably alter the mechanical propertues of SYNROC. We believe the compressive strength of 810 MPa reported by Ringwood ${ }^{10}$ may be high due to the low $L$ ' $D$ ratios of the samples tested. W' have also found compressive strengths as high as 847 MPa on SYNROC sumples with L. D ratios of 3.5.

The mitrohardness values in Table + show a characteristic decrease with increasing indenter load. There is no significant variation from edge to center in the hardness. The values taken under $100-\mathrm{g}$ loads are of the order of $1000 \mathrm{~kg}$ ' mn ${ }^{2}$. This contpares very witl with the work of Hirthe 25 who measured the microhardness of rear stoichiometric single-crystal rutile ( $\mathrm{TiO}_{2}$ ) along the (111) plane. In these experiments, using d $200-\mathrm{g}$ loud. Hirthe found values that ranged from a low of $960 \mathrm{~kg} / \mathrm{mm}^{2}$ at a $90^{\circ}$-indenter orientation to a high of $1040 \mathrm{~kg} / \mathrm{mm}^{2}$ at $180^{\circ}$-indenter orientation. Hirthe also found that slightly reduced titanis. $\mathrm{TiO}_{1.998}$, showed a higher hardness with values ranging from $1000 \mathrm{~kg} / \mathrm{mm}^{2}$ at 
$90^{\circ}$ to $1140 \mathrm{~kg} / \mathrm{mm}^{2}$ at $180^{\circ} \mathrm{C}$. We believe SYNROC hot pressed in graphite is in a slightiy reduced state.

A plot of expansion versus temperature for a sample cut from a center location is showit in Fig. 9. Data for the first and second runs show a sligit change in expansion behavior on the second run. The sample cut from an edge location showed similar behavior. The results of both runs are expressed in Table 5 as expansion coefficients $(\alpha)$ for several temperature ranges. The low-temperature coefficients for edge and center locutions in the range of 22 to $80^{\circ} \mathrm{C}$ are inconsistent. The edge location showed a $20 \%$ increase in $\alpha$ during reheat, and the center sample showed no change. For coefficients calculated at higher ranges $\left(22\right.$ to $264^{\circ} \mathrm{C}$ and above) both samples show 3 to $8 \%$ increases in $\alpha$ during reheat. We believe this indicates some residual stress existed in the hot-pressed samples, which was relieved during the first run.

The overall expansion behavior for multiphase SYNROC is comparable to other titanate ceramics. For comparison. we list the reported coefficients of other titanates together with SYNROC in Table 6. The expansion of SYNROC B is about the same as that reported by Eichelberger ${ }^{27}$ for synthetic polycrystalline $\mathrm{CaTiO}_{3}$ (perovskite), cold pressed and sintered at $1600^{\circ} \mathrm{C}$.

The thermal conductivity of LLNL SYNROC B measured at room temperature was $2 \mathrm{~W} / \mathrm{m} /{ }^{\circ} \mathrm{C}$. Higher values have been measured on SYNROC C prepared by Reeve et al. ${ }^{2 B}$ at the Australian Atomic Energy Commission. They measured thermal diffusivity and specific heat as a function of temperature up to $973 \mathrm{~K}$ and calculated thermal conductivity according to the relation:

$$
a=\frac{k}{\rho \cdot C_{p}}
$$

where $a$ is thermal diffusivity, $k$ is thermal conductivity. $C_{p}$ is specific heat. and $\rho$ is density. These values are listed in Table 7 along with values for $\mathrm{TiO}_{2}$ and other titana es similar to SYNROC. The value for SYNROC $C$ at room temperature as measured by Reeve et al ${ }^{28}$ is $4.0 \mathrm{~W} / \mathrm{m} /{ }^{\circ} \mathrm{C}$ or twice the value we measured for SYNROC B. We believe the value of $4.0 \mathrm{~W} / \mathrm{m} /{ }^{\circ} \mathrm{C}$ is more reliable because a more accurate method of measurement was employed. For comparison. the value for polycrystaliine $\mathrm{TiO}_{2}$ is $8.4 \mathrm{~W} / \mathrm{m} /{ }^{\circ} \mathrm{C}$, and the values for single-crystal $\mathrm{BaTiO}_{3}$ and $\mathrm{SrTiO}_{3}$ are 5.7 and 11.2

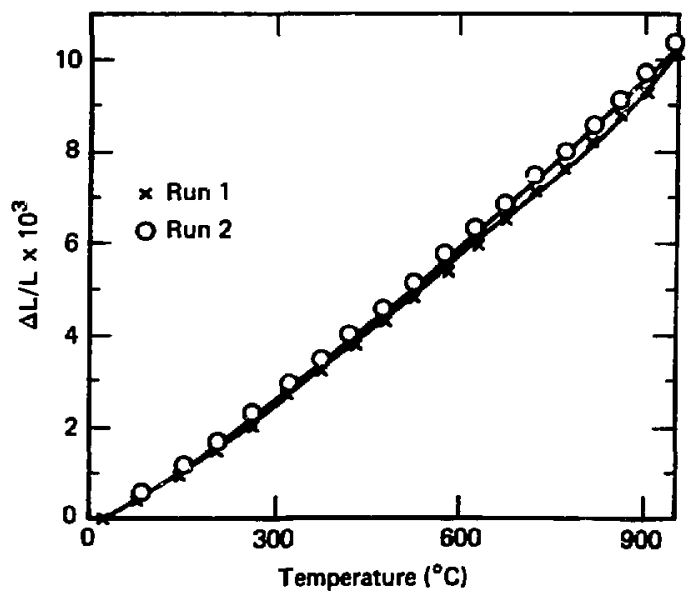

FIG. 9. Thermal expansiow of SYNROC B. (Specienen of MOSHP4A Iaken from center region of sumple disc.) 
TABLE 5. Thermal expamion of SYNROC B."

\begin{tabular}{|c|c|c|c|c|}
\hline \multirow{3}{*}{$\begin{array}{c}\text { Thermal-expansion } \\
\text { temip. range } \\
\left({ }^{\circ} \mathrm{C}\right)\end{array}$} & \multicolumn{4}{|c|}{ Expansica coefiticien (a $\times 10^{6}$ ) } \\
\hline & \multicolumn{2}{|c|}{ Ele lecation } & \multicolumn{2}{|c|}{ Center becation } \\
\hline & Ist ran & $2 a d n$ & Ist ru & $2 n d \mathrm{rta}$ \\
\hline $22-80$ & 6.93 & 8.84 & 8.32 & B. .32 \\
\hline $22-264$ & 8.7. & 5.41 & 8.68 & 9.30 \\
\hline $22-425$ & 9.38 & 9.63 & 9.46 & 9.85 \\
\hline $22-625$ & 9.79 & 10.99 & 10.03 & 10.40 \\
\hline 22-814 & 10.12 & 10.44 & 10.38 & 10.83 \\
\hline $22-949$ & 10.47 & 10.81 & 10.83 & 11.04 \\
\hline
\end{tabular}

"Specimess cut from MOSHP4A sumple (15.2-cm diam) that had been hot pressed at $1230^{\circ} \mathrm{C}, 2600$ psi for I hour, to a dexisity of 4.23 $\mathrm{g} / \mathrm{mm}^{3}$ (approximately 100 th theoretical density).

TABLE 6. Thermal-expansion coefficients of various litanates and SYNROC B.*

\begin{tabular}{|c|c|c|c|}
\hline \multirow[b]{2}{*}{ Materist } & \multicolumn{3}{|c|}{ Exparslon coefficien (a $\times 10^{6}$, } \\
\hline & $22-250^{\circ} \mathrm{C}$ & $22-609^{\circ} \mathrm{C}$ & $22-950^{\circ} \mathrm{C}$ \\
\hline $\begin{array}{l}\mathrm{riO}_{2} \text {, matile, } \\
\text { podycrystaltine }\end{array}$ & 7.3 & 8.8 & 9.6 \\
\hline $\begin{array}{l}\text { BuTIO }_{3} \text { (burium titenate. } \\
\text { polycrysalline) }\end{array}$ & 5.6 & I0.9 & 14.4 \\
\hline $\begin{array}{l}\text { CaTiO }_{3} \text { (calcbing timanie, } \\
\text { polycrystalliae) }\end{array}$ & 8.8 & 10.5 & 11.4 \\
\hline SYNROC B & 9.4 & 10.2 & 10.5 \\
\hline
\end{tabular}

On the recoud nun. SYNROC B values were averaged for both edge and center sumples.

Wim $/{ }^{\circ} \mathrm{C}$. respectively. Polycrystalline values for these titanates are significantly below the singlecry'stal values. The wide spread in the values at room temperature cannot be due entirely to grain boundary and porosity effects of the polycrystalline materials at high density. Both hot-pressed SYNROC materials were approximately $99 \%$ of theoretical density.

Charvat and Kingery ${ }^{29}$ studied the effect of microstructure and porosity on the thermal conducivity of ceramics. They found good agreement between the thermal conductivity values of single crystals and the corresponding, pure, dense polycrystalline material at temperatures below the onset of radiant-heat transfer. For titania, radiantheat transfet becomes significant at temperatures above 400 to $500^{\circ} \mathrm{C}$. In the case of $\mathrm{TiO}_{2}$, they also noted a strong influence of crystal-orientation ef- fects on thermal conductivity. At $400^{\circ} \mathrm{C}$, values were approximately $7.5,5.4$, and $5.0 \mathrm{~W} / \mathrm{m} /{ }^{\circ} \mathrm{C}$. respectively, for single crystals parallel to the c-axis, those perpendicular to c-axis, and for polycrystalline $\mathrm{TiO}_{2}$ corrected to zeĩu porosity.

Charvat and $\bar{K}^{-}$ingery ${ }^{29}$ found that pore corrections could be made for isometric pores according to the relation

$$
K_{s}=K_{p} i(I-p)
$$

where $K_{s}$ is the conductivity of the solid, $K_{p}$ is the experimental ronductivity, and $p$ is the pore fraction. Because of the anisotropic nature of $\mathrm{TiO}_{2}$, irregular, nonisometric-shaped pores in some $\mathrm{TiO}_{2}$ microstructures did not follow this relation. 
TABLE 7. Thermal conductivity of $\mathrm{TiO}_{2}$, titunates, and SYNROC b and C.

\begin{tabular}{|c|c|c|c|c|c|c|c|}
\hline \multirow[b]{2}{*}{ Maserial $^{27}$} & \multicolumn{7}{|c|}{ Thermal condurtivity $(W / m / K$ ) } \\
\hline & $300 \mathrm{~K}$ & $400 \mathrm{~K}$ & $500 \mathrm{~K}$ & $600 \mathrm{~K}$ & $800 \mathrm{~K}$ & $1000 \mathrm{~K}$ & I210 K \\
\hline $\begin{array}{l}\mathrm{TiO}_{2}: \\
\quad \text { Polycrystalline" }\end{array}$ & 8.4 & 7.0 & 5.9 & 5.0 & 3.9 & 3.5 & 3.3 \\
\hline $\mathrm{BaTTO}_{3}=$ & & & & & & & \\
\hline Single crystal & 5.7 & 4.6 & - & - & - & - & - \\
\hline Polycrystalline & $1-4$ & - & - & - & - & - & - \\
\hline $\mathrm{CaTiO}_{3}$ & & & & & & & \\
\hline Polycrystalline & $3-5$ & 3.5 & - & - & - & - & - \\
\hline $\operatorname{SrTiO}_{\mathbf{y}}:$ & & & & & & & \\
\hline Siagle crystal & 11.2 & - & - & - & - & - & - \\
\hline Pniycrystalline ${ }^{b}$ & 5.5 & - & - & - & - & - & - \\
\hline SYNROC B & 2.0 & - & - & - & - & - & - \\
\hline SYNROC 29 & 4.0 & - & - & 5.0 & - & 6.6 & - \\
\hline
\end{tabular}

$99.5 \%$ pare. $98.0 \%$ theoreticel jensity.

$b_{94 \%}$ theoretical density.

However, the microstructure of SYNROC B (see Fig. 7) indicates that the small amouni of remaining porosity is isometric. If we use the priceding expression for pore correction, the measured porosity values for the two SYNROC samples and $\mathrm{TiO}$, are witisin $2 \%$ of those for a fully dense solid. The large difference in values between single crystals of $\mathrm{BaTiO}_{3}$ and of $\mathrm{SrTiO}_{3}$ indicates that chemical composition has a strong influence on titanate thermal conductivity.

\section{CONCLUSIONS}

The SYNROC B mineral waste form can be hot pressed in graphite at $1200^{\circ} \mathrm{C}$ into a dense ceramic monolith. The mechanical and thermophysical properties are typical of titanate ceramics. The properties of SYNROC C containirg $10 \%$ simulated commercial waste are similiar to SYNROC B, indicating no adverse degradation in properties as a result of waste additions. The properties of SYNROC with waste loadings higher than $10 \%$ are unexplored, however, and additional studies are needed to establish the relation between these properties and the waste loading of SYNROC. 


\section{REFERENCES}

1. A. E. Ringwood. Safe Disposal of High-Level Nuclear Reactor Wastes: A Nen Strategr; Australian National University Press, Canberra, Australia (1978).

2. A. E. Ringwood, V. M. Overshy, S. E. Kesson, W. Sinclair, N. Ware, W. Hibberson, and A. Major, "Immobilization of High Level Nuclear Reactor Wastes in SYNROC: A Current Appraisal," $J$. Nucl. Chem. Waste Management (1981), in press.

3. A. E. Ringwood, S. E. Kesson. N. G. Ware, W. O. Hibb:rson, and A. Major, "The SYNROC Process: A Geochemical Approach to Nuclear Waste Immobilization," Geochem. J. 13, 141-165 (1979).

4. A. E. Ringwood, Safe Disposal of High-Level Radioactive Wastes. A ustralian National University, Canberra, Australia, Publ. No. 1438 (1980).

5. D. G. Coles and F. Bazan, Continuous Flow Leaching Studies of Crushed and Cored SYNROC. I. awrence Livermore National Laboratory, Civermore. Calif., UCRL-\$4679 (1980).

6. A. E. Ringwood and S. E. Kesson, "Immobilization of High-Level Wastes in SYNROC Titanate Ceramic," in Proceedings of Conference on Ceramics in Nuclear Wasce Management. Cincinnati, Ohio. April 30-May 2, 1979 (CONF-790420).

7. H. W. Newkirk, C. L. Hoenig. F. J. Ryerson, J. D. Tewhey, G. S. Smith, C. C. Rossington, A. J. Brackmann, and A. E. Ringwood, Status of SYNROC D Technology for Immobilizing U.S. Defense Wastes, Lawrence Livermore National Laboratory, Livermore, Calif., UCRL-84395 (1981).

8. J. Tewhey, H. Newkirk, F. Ryerson, D. Coles, C. Hoenig, R. Rozsa, C. Rossington, and F. Bazan. Phase Equilibria. Leaching Characteristics. and Ceramic Processing of SYNROC D Formulations for $\boldsymbol{C}$. S. Defense Wastes, Lawrence Livermore National Laboratory, Livermore, Calif., UCRL-83658 (1981).

9. J. D. Tewhey, C. L. Hoenig. H. W. Newkirk, R. B. Rozsa, D. G. Coles, and F. J. Ryerson, The Application of SYNROC to High-Level Defense Wastes, Lawrence Livermore National Laboratory. Livermore. Calif., UCRL-85032 (1980).

10. A. E. Ringwood, W. Sinclair, and G. M. McLaughlin, Nuclear Waste Immobilization, Lawrence Livermore National Laboratory, Livermore, Calif., UCRL-15457 (1979).

11. J. Campbell, C. Hoenig, F. Ryerson, F. Bazan, T. Wolery, M. Guinan, R. Rozsa, and R. Van Konynenburg, "Imobilization: of High-Level Defense Wastes in SYNROC: An tppraisal of Product Performance," presented at conference on High-Level Waste Technical Review, Atlania, Ga., Mav18-19. 1981: also Lawrence Livermore National Laboratory, Report UCRL-85913 (April 28. 1981).

12. R. H, Marion and J. K. Johnstone, A Parametric Study of the Diametral Conipression Test for Ceramics. Sandia Laboratories, Albuquerque, N. Mes., SAND-75-0347 (1975).

13. R. M. Spriggs, L. A. Brissette, and T. Vasilos, "Tensile Strengths of Dense Polycrystalline Ceramics by the Diametral-Compression Test," Mater. Res. Stand. 4, 218 (1964).

14. A. Rudnick, A. R. Hunter, and F. C. Holden, "An Analysis of the Diametral Compression Test," Mater. Res. Stand. 3, 283-289 (1763).

15. American Society for Testing Materials, "Standard Test Methods for Flexural Properties of Plastics and Electrical Insulating Materials," in 1979 Annual Book of ASTM Standards: Part 35. Plastics General Test Methods (ASTM, Philadelphia, Pa., 1979). Specification D-790-71. p. 329.

16. American Society for Testing Materials, "Standard Test Methods for Compressive Strength of Fired Whiteware Materials," in 1979 Amnual Book of ASTM Slandards: Part 13. Electronics (ASTM. Philadelphia, Pa., 1979), Specification C-773-74, pp. 15-18.

17. H. Seki, A. Granato, and R. Truell, "Diffraction Effects in the Uttrasonic Field of a Piston Source and Their Importance in the Accurate Measurement of Attenuation," J. Acous. Sac. Am. 28. 230-238 (1956).

18. H. J. MzSkimin, in Physical Acoustics, Vol. 1, Part A, W. P. Mason, Ed. (Academic Press. Inc.. New York, 1964), Chapter 4.

19. H. J. McSkimin, "Pulse Superposition Method for Measuring Ultrasonic Wave Velocities in Solids." J. Acoust. Soc. Am. 33, 12-16 (1961).

20. H. J. McSkimin and P. Andreatch, Jr., "Elastic Moduli of Germanium Versus Hydrostatic Pressure at 25.0 ${ }^{\circ} \mathrm{C}$ and $-195.8^{\circ} \mathrm{C}, *$ J. Appl. Phys. 34, 651-655 (1963). 
21. E. Schreiber and O. L. Anderson, "Pressure Derivatives of the Sound Vylocities of Polycrystalline Álumina," I. Am. Ceram. Soc. 49, 184-190 (1966).

22. E. P. Papadakis and K. A. Fowler, "Broadband Transducers: Radiation Field and Selected Applications," J. Acous. Soc. Am. 50, 729-745 (1971).

23. E. P. Papadakis, "Absolute Accuracy of the Pulse-Echo Overlap Method and the Pulse-Superposition Method for Ultrasonic Velocity," J. Acoks. Soc. Am. 52, 843-846 (1972).

24. E. P. Papadakis, "Ultrasonic Diffraction Loss and Phase Change in Anisotropic Materials," J. Acous. Soc. Am. 40, 863-876 (1966).

25. W. M. Hirthe, D. R. McCann, and E. H. Greener, "Influence of a Departure from Stoichiometry on the Microhardness of Rutile at Room Te nperature," Trans. Am. Soc. Mech. Eng. 227, 1467-1468 (1967).

26. Y. S. Touloukian, Ed., Thermophysical Properties of Matter (Plenum Publishing Corp., New York, 1977), Vol. 13: Thermal Expansion of Nonmetallic Solids, and Yol. 2: Thermal Conductivity. Nonmetallic Solids.

27. R. L. Eichelberger, "Lime Bonded and Stabilized with Titanium Oiside as a Refractory for Special Applications," U. S. Atomic Energy Commission, Rept. No. 8, 25 (1954).

28. K. D. Reeve, D. M. Levins, E. J. Ramm, J. L. Woolfrey, W. J. Buykx, R. K. Ryan. and J. F. Chapman, "The Development and Testing of SYNROC for High-Level Radioactive Waste Fixation," Waste Managenent 1981, American Nuclenr Society, February 23-26, 1981.

29. F. R. Charvat and W. D. Kingery, "Thermal Conductivity: XIII. Effect of Microstructure on Conductivity of Single-Phase Ceramics," J. Am. Ceram. Soc. 40, 306-315 (1957). 